\title{
Bütünleşik Afet Yönetimine Sosyolojik Bakış: Toplumsal Yapı, İşlev ve Temel Kavramlar Işı̆̆ında Bir Okuma Denemesi
}

\author{
Ruhi Can ALKIN \\ Dr., Necmettin Erbakan Üniversitesi, SBBF, Sosyoloji Bölümü, Konya, Türkiye \\ ruhicanalkin@gmail.com
}

\begin{tabular}{|c|c|}
\hline Makale Bilgileri & ÖZ \\
\hline $\begin{array}{l}\text { Makale Geçmişi } \\
\text { Geliş: 07.04.2021 } \\
\text { Kabul: } 15.06 .2021 \\
\text { Yayın: } 30.06 .2021 \\
\text { Anahtar Kelimeler: } \\
\text { Afet, Bütünleşik Afet } \\
\text { Yönetimi, Toplumsal } \\
\text { İşlev, Kolektif Bilinç, } \\
\text { Bürokrasi. }\end{array}$ & 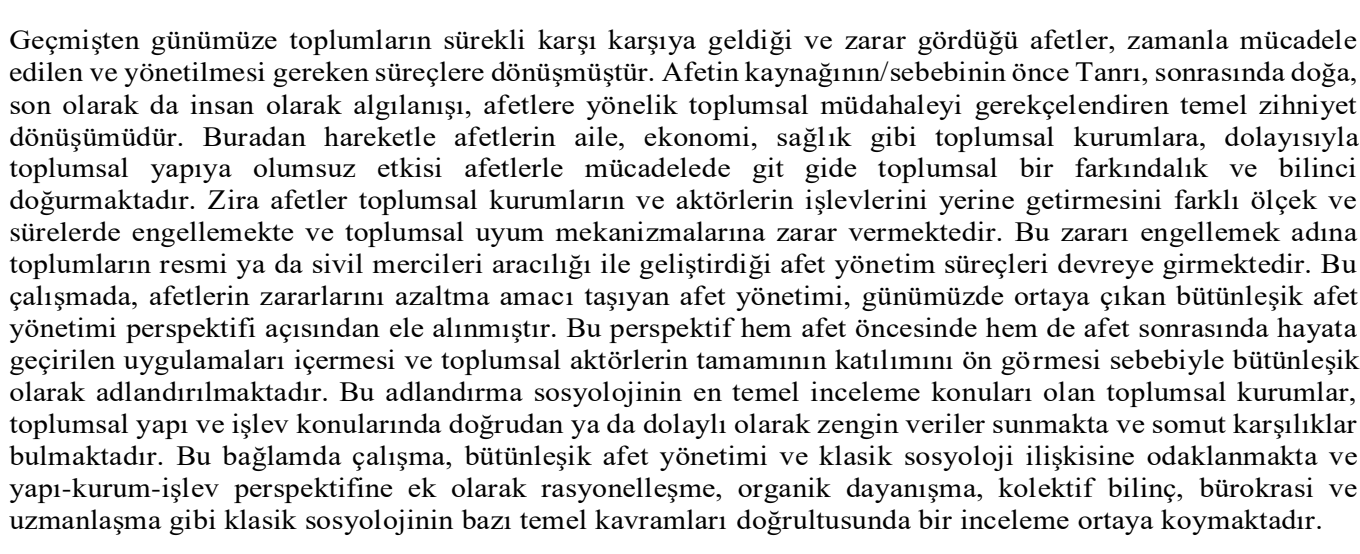 \\
\hline
\end{tabular}

\section{Sociological View on Integrated Disaster Management: A Reading Attempt in the Light of Social Structure, Function and Basic Concepts}

\begin{tabular}{|c|c|}
\hline Article Info & ABSTRACT \\
\hline $\begin{array}{l}\text { Article History } \\
\text { Received: } \quad 07.04 .2021 \\
\text { Accepted: } 15.06 .2021 \\
\text { Published: } 30.06 .2021 \\
\text { Keywords: } \\
\text { Disaster, Integrated } \\
\text { Disaster } \\
\text { Management, } \\
\text { Social Function, } \\
\text { Collective } \\
\text { Consciousness, } \\
\text { Bureaucracy. }\end{array}$ & $\begin{array}{l}\text { Disasters that have been faced by and damaged the societies from the past to the present have turned into } \\
\text { processes that have to be struggled and managed over time. The perception of the reason of disaster, firstly God, } \\
\text { then nature, and finally, human-centered, is the basic mentality transformation that justifies social intervention } \\
\text { against disasters. The perception of the source/cause of the disaster as first God, then as nature, and finally as } \\
\text { human, is the basic mentality transformation that justifies social intervention against disasters. Hence, the } \\
\text { negative impact of disasters on social institutions such as family, economy, and health, and thus on the social } \\
\text { structure, gradually creates a social awareness and consciousness in combating disasters. It is because disasters } \\
\text { prevent social institutions and actors from fulfilling their functions at different scales and durations, and also } \\
\text { damage social adaptation mechanisms. In order to prevent this damage, disaster management processes } \\
\text { developed by the official or civil authorities of the societies come into play. In this study, disaster management, } \\
\text { which aims to reduce the damages of disasters, is discussed from the perspective of today's integrated disaster } \\
\text { management. This perspective is called integrated because it includes the practices implemented both before } \\
\text { and after the disaster and it foresees the participation of all social actors. This naming provides rich data directly } \\
\text { or indirectly on social institutions, social structure, and function, which are the most fundamental study subjects } \\
\text { of sociology, and finds concrete responses. In this context, the study focuses on the relationship between } \\
\text { integrated disaster management and classical sociology, and in addition to the structure-institution-function } \\
\text { perspective, it presents an examination in line with the some of the basic concepts of classical sociology such } \\
\text { as rationalization, organic solidarity, collective consciousness, bureaucracy, and specialization. }\end{array}$ \\
\hline
\end{tabular}

Atıf/Citation: Alkın RC. (2021). Bütünleşik Afet Yönetimine Sosyolojik Bakış: Toplumsal Yapı, İşlev ve Temel Kavramlar Işığında Bir Okuma Denemesi Medeniyet ve Toplum Dergisi, 5(1), 18-34.

"This article is licensed under a Creative Commons Attribution-NonCommercial 4.0 International License (CC BY-NC 4.0)" 


\section{GİRIŞ}

Doğa olaylarının ya da insan eylemlerinin sonuçları olarak meydana gelen yıkım ya da kayıpları niteleyen afetler, temeli itibariyle toplumsal yapı ve işleyişe zarar veren durumlardır. Afetlerin sosyolojinin bir alt dalı olarak müstakil bir disiplin haline gelişindeki ana gerekçe bu zarar ve zarardan kaynaklı toplumsal değişmedir.

Afetlerin kaynağı, insanlık tarihi boyunca üç temel farklı alanda aranmıştır. Bunlardan ilki, Tanrı'nın insanları cezalandırma yolu olarak farklı zaman ve bölgelerde afetler meydana getirmesidir. $\mathrm{Bu}$ bakış, modern öncesi dönemde afetlere dair temel yaklaşımı temsil etmektedir. İkinci olarak, sekülerleşme süreci ile afetin kaynağındaki Tanrı algısı, yerini doğanın failliğine bırakmıştır. Modern insan ya da modern toplumun doğaya yönelik hakimiyet istenci, afetlerin kaynağında "kendisiyle baş edilemeyen doğa"yı konumlandırmıştır. Fakat 20. yüzyılın ortalarına doğru insan eliyle ortaya çıkan Dünya Savaşları, nükleer tehditler gibi yıkıcı gelişmelerin etkisi ile yapay afet kategorisinde nicel bir genişleme oluşmuştur. Buna ek olarak doğal olarak adlandırılan afetlerin yarattığ yıkım ve kayıplarda afet öncesi dönemden kalma insan hatasının da görülmesi ile afetlerin kaynağına yönelik algı ve yorumlarda insan merkezlilik ya da insanın failliği ön plana çıkmıştır.

Afetin sebebinin insana dayandırılması, toplumlara zarar veren bu olaylarla mücadelede yine insana ve toplumsal aktörlere odaklanılmasına sebep olmuştur. Güncel afet sosyolojisi literatürüne şekil veren bu perspektif, afetleri bizzat insani çaba ile mücadele edilmesi gereken bir konuma taşımıştır. $\mathrm{Bu}$ sebeple, güncel afet sosyolojisi literatüründe afet yönetimi konusu geniş bir araştırma alanı kazanmıştır. Afet yönetimi başlangıçta afet sonrası aşamalara odaklanan bir perspektiftir. İnsanın başlıca fail olarak algılandığı doğal ya da yapay afetlerde, gelişen teknoloji ve çok disiplinli bakış açısı ile afet öncesi alınacak önlemlerin afetin zararlarını azaltmada kritik bir önem taşıdığının farkına varılması, yeni bir afet yönetimi perspektifini ortaya çıkarmıştır: Bütünleşik afet yönetimi.

Bütünleşik afet yönetimi, afet merkezli bir zamansallık kurgusundan hareketle, afet öncesinde alınacak tedbirleri ve afete dair toplumsal farkındalığı amaçlamakta, afet sonrasında ise belli aşamalar ekseninde afetin etkilerini azaltmayı hedeflemektedir. Diğer bir ifadeyle afetle mücadeleyi yalnızca afet sonrası adımlarla sınırlandırmamakta, afetler meydana gelmeden önce alınacak tedbirlere, izlenecek politikalara ve hayata geçirilecek uygulamalara yer vermektedir.

Bütünleşik afet yönetimi, her bir toplumsal kurumun ve aktörün katılımcı bir şekilde inisiyatif alması beklenen aşamaları içermektedir. Zira afetin yaşandığı bölge ya da ülke çapında yıkım ve tahribat oluşturması, o bölgenin toplumsal yapısının, kurumlarının, işeyişinin ve aktörlerinin zarar gördüğü anlamına gelmektedir. Bu da kısa, orta ya da uzun vadede bireyler ve toplumlar için olumsuz sonuçlar üretmektedir. Toplumsal organizma ve işlev kuramı açısından her toplumun düzenini koruma ya da bozulan düzenini tamir etme refleksi taşıdığı ön görüsünden hareketle, bütünleşik afet yönetimi afet sonrası bozulan toplumsal yapı, zarar gören toplumsal kurumlar ve bireysel yaşamları yeniden düzene koymayı, afet öncesinde bu bozulmayı en düşük seviyede tutmayı ve bunu her bir toplumsal kurum ve aktörün katılımıyla gerçekleştirmeyi hedeflemektedir. Bu hedefe ulaşmak açısından hesaplamalar, risk analizleri, simülasyon çalışmaları gibi teknik detayların da olduğu profesyonel süreçlere başvurulmaktadır.

$\mathrm{Bu}$ argümanlardan hareketle bütünleşik afet yönetiminin, bizzat sosyolojinin araştırma alanları ile alakalı bir uğraşı olduğu söylenebilir. Bahsedilen kurum, yapı ve işlev çerçevesinden hareketle, bütünleşik afet yönetiminde ortaya çıkan eylem, beklenti, farkındalık ve politikalar, sosyolojinin kuruluş aşamasında rastlanan birtakım kavramlara dair veriler sunmaktadır. Bu kavramlar arasında bürokrasi, kolektif bilinç, organik dayanışma, uzmanlaşma, bürokrasi ve rasyonalite mevcuttur.

$\mathrm{Bu}$ çalışmada, bütünleşik afet yönetimi ile bir bilim olarak sosyoloji ve klasik sosyolojinin bazı temel kavramları arasındaki ilişki ele alınmıştır. Bu bağlamda çalışmanın temel iddiası, günümüzde daha çok sivil savunma, kamu yönetimi ya da sosyal hizmet gibi disiplinlerin uğraşı alanı olarak belirse de bütünleşik afet yönetiminin, ele aldığı konular ve pratiğini meydana getiren aktörler açısından temelde sosyolojinin bir inceleme alanı olduğudur. Bu iddiayı desteklemek adına sosyolojinin kurucuları tarafından üretilen toplumsal yapı, işlev, değişme, kurumlar konusu ve yukarıda bahsi geçen toplumsal dayanışma, kolektif bilinç gibi kavramlar, günümüz bütünleşik afet yönetimi algısı ve uygulamaları baz 
alınarak tartışılmış ve örneklendirilmiştir. $\mathrm{Bu}$ tartışma ve örneklendirmeler vesilesiyle klasik sosyolojinin afet ve toplum ile afet yönetimi konusunda ürettiği argümanlar ortaya konulmuştur.

\section{AFET VE AFET YÖNETIMI: TOPLUMSALLIK MERKEZLİ BİR}

\section{DEĞERLENDİRME}

Tarih boyunca toplumların yaşadığı afetler doğal ve yapay olmak üzere iki temel kategoriye sahip olsa da (Turner ve Pidgeon, 1997: 19) günümüzde yaşanan bazı afetler doğanın reaksiyonları ile insan etkisinin bir araya gelmesi şeklinde karma bir arka planla ortaya çıkabilmektedir. ${ }^{1}$ Ancak kaynağı ve sonuçları hangi kategoride değerlendiriliyor olursa olsun, her bir afetin toplumsal yapı ve işleyişe olumsuz etki ettiği sabittir. Bu sebeple afetlerle ilgili sosyal bilimsel çalışmalar, oluşan etkilerin doğurduğu sosyal ve davranıșsal reaksiyonlara odaklanmaktadır (Lindell, 2013: 797). Afet tanımları, bu etkinin, reaksiyonun ve toplumsallı̆̆ın görülmesi açısından önemli veriler sunmaktadır. Güncel bir tanım üzerinden gidilecek olursa, 2020 yılının sonunda Türkiye'de yayımlanan Afet Sosyolojisi adlı derlemede afet şu şekilde tanımlanmaktadır:

"İnsan topluluklarınin yaşadiğ yerlerde aniden veya zamanla oluşan, gerek doğanın olağan devinimiyle gerekse de insanın doğrudan veya dolaylı müdahalesiyle gerçekleşen; fiziksel ekonomik, psikolojik ve daha birçok yönden büyük hasarlara ve kayıplara neden olan ve etkileri bakımından önemli toplumsal sonuçlar doğuran sosyal bir olgudur" (Can, 2020: 20).

Gözlenebileceği üzere afet tanımı ve bu tanımın hemen her bileşeni toplumsallık arka planına sahiptir. Afet sonrası dönem için vurgulanan sonuçlar, toplumsal kurumlarda ve toplumsal işleyiş açısından meydana gelecek değişimleri ifade etmektedir. Bu sebeple afetin sebep olduğu yıkımın ölçek, kapsam ve süre açısından boyutu ne kadar büyükse, sosyal yapı da o oranda etkilenir (Fischer, 2013: 96).

Öte yandan, afetlerin toplumsallığı ve sosyoloji-afet ilişkisinin arka planı, bir olayın bizzat afet olarak adlandırılması ile alakalıdır. Şöyle ki, herhangi bir doğa olayının ya da insanın yarattığ tahribatın afet olarak nitelenmesi, o toplum ya da topluluk için bir etki ya da dönüşüm söz konusu olduğunda mümkündür. AFAD'ın afet tanımında bu durumun daha detaylı algılanması açısından önemli bir ifade mevcuttur: "Toplumun tamamı veya belli kesimleri için fiziksel, ekonomik ve sosyal kayıplar doğuran, normal hayatı ve insan faaliyetlerini durduran veya kesintiye uğratan, etkilenen toplumun baş etme kapasitesinin yeterli olmadığı doğa, teknoloji veya insan kaynaklı olay. Afet bir olayın kendisi değil, doğurduğu sonuçtur" (AFAD, 2021a). Bu sonuç, tek başına bir bireyi ilgilendiren ya da insan topluluklarının etkisine maruz kalmadığı herhangi bir olayı nitelememektedir. Daha geniş bir bağlamda, ortaya çıkan değişmenin bizzat toplumu ilgilendirmesi ile alakalıdır. Bu sebeple afet olarak adlandırılmada toplumsal yapı, işeyiş ve kurumlar açısından doğan zararlar belirleyici olmaktadır. Fakat her halükârda meydana gelen afet sonucu aile, ekonomi, sağlık, eğitim gibi toplumsal kurumlar zarar görmekte, işlevlerini belli bir süreliğine yerine getirememekte ve bu kurumların aktörleri olan bireyler, toplum yaşantılarına ilişkin farklı ölçülerde problemler yaşamaktadır.

Afetlerle mücadeleyi içeren afet yönetimi konusu da afetin toplumsallığından çıkış noktası bulamaktadır. Bu mücadele, afetin zararlarını azaltmak, afete hazırlıklı olmak, afetin ortaya çıkmasını engellemek ya da afetin daha az zararla ortaya çıkışını sağlamak şeklinde bazı temel kategorilere sahiptir (Carter, 2008: 25-27). Bu kategoriler, 1930'lu y1llardan itibaren afet yönetim döngüsü (disaster management cycle) olarak literatürde yer bulmuştur (Neal 1997'den akt. Coetzee ve Van Niekerk, 2012: 1; Toprak Karaman, 2016: 4). Bu döngü, afet yönetimini daha çok afet sonrası aşamalara odaklanan geleneksel perspektiften (Philips vd., 2012: 14) çıkarıp,

\footnotetext{
${ }^{1}$ Hatta bu konuda Steve Matthewman'ın Disasters, Risks and Revelation (2015) başlıklı çalışması, afetlerde doğaya atfedilen failliği sorgulayan bir alt bölüm içermektedir. Is There Such a Thing as a Natural Disaster? başlıklı bu bölüm (s. 25-31), ister salgın ister deprem isterse de kasırga halinde oluşsun, afetin ortaya çıkışında doğanın suçlanamayacağını, her bir afette mutlak surette insan hatası, ihmali ya da suçu olduğunu ifade eden argümanları ve örnekleri içermektedir. Bu açıdan Matthewman'a göre afetlerin tamamı yapay/insan eliyle yaratılan yıkım ve kayıplardır.
} 
bunu afet öncesi, afet esnası ve afet sonrası atılacak adımları içeren bir sürekliliğe kavuşturan aşamaları içermektedir: Afetin oluşumu ve etkisi, müdahale, iyileştirme, geliştirme, engelleme, hafifletme ve hazırlıklı olma (Quarantelli, 2003: 4; Ekşi, 2016: 75; Alexander, 2012). Afet yönetimine dair tanımlar ve temel argümanlar, öncesi ve sonrasiyla afet yönetim döngüsünün daha da netleşmesi açısından yol gösterici niteliktedir. Örneğin, Ergünay’a (akt. Şengün, 2018: 136) göre afet yönetimi, "afetlerin önlenmesi ve zararlarının azaltılması, afetlere karşı hazırlıklı olunması, afet anında hızl, etkili bir arama kurtarma, ilkyardım, geçici barınma ve yeniden yapım faaliyetlerinin yürütülebilmesi için, toplumun tüm olanak ve kaynaklarının akılcı bir biçimde kullanılmasını ve yönetilmesini gerektiren çok genel bir kavramdır”. Özdikmen'in (2019: 21) tanımına göre ise afet yönetimi, "afetlerin önlenmesi ve zararların azaltılması için afet öncesi, afet sırası ve afet sonrasında yapılması gereken idari, yasal ve teknik çalışmaları belirleyen ve uygulamaya aktaran, bir olay zamanında uygulama yapabilmeyi sağlayan ve her olaydan çıkarılan derslerin 1şı̆̆ında mevcut sistemi geliştiren yönetim biçimidir”. Teknik bilgi ve vurgularla şekillendirilen bu tanım, afet yönetimini bir sistem olarak ele almakta ve bu sistemin her bir afet tecrübesi ile revizyonunu ve gelişimini ön görmektedir.

Afet yönetimi tanımlarıyla bağlantılı olarak modern afet yönetiminde hazırlıklı olma ve önleme merkezli bir yaklaşımın mevcut olduğu söylenebilir. "Modern afet yönetim sistemleri afetler meydana gelmeden önce afet tehlike ve risklerine karşı önlem almayı, afet tehlike ve risklerine karşı toplumları eğitmeyi, bilinçlendirmeyi ve afetlere karşı direnç kazandırmayı afet yönetim sisteminin en önemli aşaması olarak görmektedir" (Çakır ve Artun, 2020: 64). Bu bakış açısı, afetleri her an göz önünde bulundurmayı içeren bir farkındalı̆̆ 1 ve toplumsal yaşantının organizasyonunda afet tehlike ve risklerini hesaba katmayı ögütler. Bu yönüyle sürekli bir afet gündemi ile sürdürülebilir bir afet yönetimine işaret etmektedir. $\mathrm{Bu}$ da toplumun üyelerinin afet konusunda eğitilmesi ve afete dirençli hale getirilmesi adımlarını ön plana çıkarmaktadır.

Afet yönetiminin geleneksel modelden farklı olarak afet öncesi aşamalara daha fazla önem ve yer vermesi, afet yönetim döngüsünde de gözlenebilir. Bu döngüdeki 2 temel aşama olan müdahale ve iyileştirme afet sonrasına işaret etmekteyken, afet öncesindeki geliştirme, engelleme ve hazırlıklı olma aşamaları, bir sonraki muhtemel afetin ya da diğer türden afetlerin hazırlığ niteliğindedir. $\mathrm{Bu}$ aşamalar, bir açıdan da afet sonrası müdahalenin başarısını doğrudan ya da dolaylı olarak etkilemektedir (Moe ve Pathranarakul, 2006: 409-410). Söz gelimi, büyük çaplı bir deprem sonrası toplanma alanlarının belirlenmesi ya da enkaza ve afetzedelere acil müdahale anında hangi kurumun hangi kaynaklarının (yaşam malzemesi, insan kaynağı, vd.) hangi sürelerde seferber edileceği gibi afet öncesi yönetim adımları, afet sonrasının müdahale ve iyileştirme aşamaları için bir hazırlık niteliğindedir.

Afet öncesi yönetim aşamaları ve bu aşamalara yönelik ilgi, afetlere yönelik toplumsal farkındalık açısından önem arz etmektedir. Zira bu aşamalar toplumsal kurumların ve aktörlerin çok kısa sürede örgütlenerek müdahale ve iyileştirme aşamalarına katkıda bulunduğu durumları ifade etse de afet öncesi yönetime dair eksiklikler ya da bu konuda herhangi bir girişimin olmaması, afetin o toplum ya da topluluk için daha fazla zarar ve kayıp doğurmasına ve bunların zamanla unutulmasına sebep olabilmektedir. Fakat afet sonrası yönetim aşamalarında gerçekleştirilen risk analizleri, bilgilendirme çalışmaları, fiziki mekanların ve coğrafyanın sağlamlaştırılması ya da ıslahı (özellikle taşkınlar açısından dere yataklarının ıslahı ya da kanallar oluşturulması), toplumun ya da afet riski olan bölgelerin sakinlerine yönelik acil durum ve ilkyardım eğitimi, haberleşme ağlarının kontrolü ve kapasite artırımı ve diğer adımlar (Ergünay, 2005: 10; Stenchion, 1997: 41) hem önceki afete dair toplumsal hafizayı diri tutmakta, hem de toplumu bir sonraki afet için teyakkuz halinde olmaya teşvik etmektedir. Bu hatırlama ve teşvik hali, vatandaşlardan sivil topluma ve resmî kurumlara değin her bir aktör açısından bir afet gündemi doğurmaktadır. Bu açıdan afet yönetim döngüsü, bizzat toplumsal yapıya, toplumsal kurumlara ve toplumsal işleyişe dair iddia, beklenti ve uygulamalar şeklinde belirmekte ve bu yönüyle sosyolojik uğraşının bir konusu haline gelmektedir. Bu durum, afet yönetiminin güncel konusu olan bütünleşik afet yönetiminde daha net bir şekilde ortaya çıkmaktadır.

\section{BÜTÜNLEŞIK AFET YÖNETIMI: SOSYAL YAPI, İŞLEV VE SOSYOLOJIKK KAVRAMLARI HATIRLAMAK}


Bütünleşik afet yönetimi, son dönem afet sosyolojisi literatüründeki akademik çalışmalarda ve ilgili kurumlar tarafından afet yönetimi ile ilgili hazırlanan mevzuat ve raporlarda sıkça rastlanan bir konudur. AFAD'ın (2021b) tanımına göre bütünleşik afet yönetimi, "afetlerle baş edebilen, dayanıklı ve dirençli bir toplum oluşturmak için tüm tehlikeleri dikkate alan, afet yönetiminin önleme, zarar azaltma, hazırlık, müdahale ve iyileştirme aşamalarında yapılması gereken çalışmalar ve alınması gereken önlemleri, toplumun tüm güç ve kaynaklarını kullanarak gerçekleştirebilen bir yönetim süreci"ni ifade eder. ${ }^{2}$ Bu kavrama dair ilk etapta dikkat çeken husus, birliktelik ve dayanışmaya ilişkin sunduğu verilerdir. Afet yönetimi konusu afetlerin öncesini de kapsaması ile literatüre yeni bir bakış açısı sunmuşken, bütünleşik afet yönetimi açısından afet döngüsünde kurumlar, aktörler ve bunlar arasındaki eşgüdüm/koordinasyon ve dayanışma ön plana çıkmaktadır. Bu açıdan, "afetlerle mücadelenin başarısında, herkesin dahil olduğu gündelik hayattaki aktivitelerde muhtemel afetlerin ve kayıların hesaba katılmasını öğütleyen bir yapıya sahiptir ve bu yönüyle afetlere ve afet yönetimine bakışta güçlü bir kültürel yaklaşım değişikliğini ortaya koyar" (Simonoviç, 2015: 81). Tanım ve argümanlar açısından afet yönetimi ve bütünleşik afet yönetimi arasında bazı benzerlikler olsa da "bütünleşik afet yönetimi tanımı, afet yönetimi tanımındaki kurum ve kuruluşlar kısıtlı söyleminden çıkıp tüm toplumun seferber olduğu bir tanım halini almıştır. Yani afetler artık yalnızca kurumların müdahale edeceği bir mesele değil; toplumdaki tüm bireylerin bilmesi, farkında olması ve müdahale etmesi gereken bir olgu halini almıştır" (Günpay, 2020: 6-7).

Afet yönetiminin bütünleşik bir yapıda ve dinamikte algılanışı, afet yönetim döngüsünde yeni aşamaları da beraberinde getirmiştir. Bütünleşik afet yönetimi evreleri, afetin oluşması, iyileştirme, geliştirme, engelleme, hafifletme ve hazırlıklı olma adımlarına ek olarak etki analizi, tahmin ve erken uyarı gibi adımları da içermektedir (Kadığlu, 2008: 9). Afet yönetim döngüsüne dahil olan bu yeni adımlar, afetlerle mücadelede teknik bağlamda daha profesyonel ve rasyonel bir yaklaşıma işaret etmektedir. Bu yaklaşımda coğrafi bilgi sistemlerinin aktivasyonundan istatistiki metotlarla yapılan risk analizlerine, afet simülasyonundan yapı denetimine ve yönetim organizasyonuna değin bilgi ve tekniğin bir araya geldiği süreçler mevcuttur (Tomaszewski, 2020; Malalgoda, vd., 2014; Mishra, vd. 2019). Bunlar, afetlerin sosyal bilimlerde ele alınışında yalnızca sosyal olgu ve fenomenlerden değil, teknik bilgiden de yola çıkılması gerektiğini göstermektedir.

Toplumsal aktörlerin, kurumların ve birimlerin koordinesi ile teknik, fiziki, coğrafi, beşerî ve iktisadi unsurların nitel ve nicel açıdan çok daha yoğun bir şekilde ele alınması, afetleri toplumun hemen her bir bileşeni tarafindan üzerinde durulan ve politika geliştirilen bir konuma kavuşturmaktadır. Bu da afetleri, öncesi ve sonrası ile toplumsal sistem ve bu sistemin bileşenleri açısından incelemeyi gerektirmektedir. Bütünleşik afet yönetimi ile sosyolojinin kesiştiği ve afet yönetiminin birtakım sosyolojik kavramlar ışığında tartışılmasının önünü açan nokta tam da burasıdır. Bu yaklaşımda en genel haliyle toplumun farklı öğeleri ve kurumları birer yapı olarak ele alınır, dışarıdan gelecek zararlara karşı yıkıcı toplumsal değişmenin önüne geçilmeye çalışılır ve her bir aşamada toplumsal kurumların ve aktörlerin işlevlerinin korunması ya da bozulan işlevlerin tamiri hedeflenir (Parsons, 1991). Bütünleşik afet yönetimi ve aşamaları, bahsedilen bu yaklaşımın teorik ve uygulamalı haline işaret etmektedir. Bu argümanların ışığında ve sosyal sistem teorisinden hareketle, sosyolojinin henüz ortaya çıtığı dönemlerde üretilen bazı kavramlar, görece yeni bir kavram olan bütünleşik afet yönetimi perspektifi ve pratikleri açısından ele alınabilir.

\subsection{Sosyal Sistem Teorisi Açısından Bütünleşik Afet Yönetimi}

Bütünleşik afet yönetiminde sosyolojik teorinin merkezinde yer alan toplumsal yap1,

\footnotetext{
2 Tanımı ve içeriği açısından bütünleşik bir afet yönetiminde en kritik noktalardan biri de afetzedelere yönelik psikososyal müdahaledir. Konunun psikoloji biliminin kapsamına yakınlığı, afete yönelik toplumsal müdahale konusunda bireyin göz ardı edilebileceği anlamına gelmemektedir. Özellikle afet sonrası psikodestek uygulamaları, afet öncesinde afetlere yönelik psikolojik hazırlıklı olma hali ve diğer süreçler (Bayhan, 2020: 286), afet ve toplum konusunda hem multidisipliner bir işlev görmekte hem de bireylerin toplumsa hayata yeniden intibakı açısından önem arz etmektedir.
} 
kurumlar ve işlev konularını şeffaflaştırmak adına Parson'un sistem teorisi biraz daha detaylı bir şekilde analiz edilebilir. Bu teorinin analizi neticesinde, sosyolojinin temel kavramlarından organik dayanışma, rasyonelleşme, iş bölümü, bürokrasi ve uzmanlaşmanın bütünleşik afet yönetimi açısından yerinin daha net gözlenebileceği öngörülmektedir.

Sosyolojinin ortaya çıkışında etkili olan ve sosyolojik teorilerle çeşitlendirilen "toplumsal hayatı bir organizma gibi ele alma" geleneğinin temsilcilerinden biri de Talcott Parsons'tur. Parsons'un kuramında toplum, çeșitli alt sistemlerden ve aktörlerin bu sistemler içinde birbirleriyle kurdukları ilişkilerden oluşmaktadır (Parsons, 2007). Toplumsal yapı olarak da ifade edilebilecek (ya da bu yapıyı doğuran) bu sistemde, her bir unsurun işlevselci bir bakış açısıyla ele alındığı görülmektedir. Bu bakış açısı, aktörlerin toplumsal beklentiler doğrultusunda hareketini ve herhangi bir uyumsuzluk ya da bozuklukta bu beklentiler doğrultusunda bir telafiyi ön görmektedir. Yakalanmaya çalışılan uyum, Parsons'ta bütünleşmenin korunması açısından "gerilim yönetimi” kavramıyla açığa çıkar (Swingewood, 1998'den akt. Yıldırım, 2020: 163). Bu kavram, en genel haliyle toplumda ortaya çıkan işlevsel taleplerin karşılanmasını ve bunların yol açabileceği muhtemel çatışma halinin sistem tarafından telafi edilmesini ifade eder (Fidan, 2017: 270).

Parsons, bir sosyal sistem içerisindeki bireylerin toplumsal eylemlerine yön veren temel referans noktalarını sosyal aksiyon kuramı çerçevesinde açıklar. Buna göre, bireyin dahil olduğu organizma, kişilik sistemi, sosyal sistem ve kültürel sistem gibi alt bileşenler mevcuttur (Baltacı, 2019: 6). Bu bileşenlerde uyum, amaca ulaşma, bütünleşme ve örüntü sürdürme gibi işlevsel kalıplar mevcuttur (Mayhew, 1982: 25). Bu kalıplar, Parsons'a göre "ihtiyaçlarının karşılanması" ön şartı ile sistemin varlığı ve devamlılığ açısından zorunluluk halini almaktadır (Layder, 2008: 42). $\mathrm{Bu}$ zorunlulukların temel motivasyonu, bir diğer ifadeyle sistemi bir arada tutan temel unsurlar, yapısal öğeler olarak değerler, normlar ve rollerdir (Marshall, 2005: 578).

Gözlenebileceği üzere Parsons, toplumsal yapıyı ve işleyişi organizmacı yaklaşımı temel alan sistem kuramı üzerinden şekillendirmiş ve sosyal yaşantıyı açıklamada sistem, alt sistemler, yapı ve işlevi öncelemiştir. Ancak toplumun organizmacı bağlamda ele alınışı, toplumun yani sistemin aktörleri olan bireyi zorunlu olarak edilgen bir konuma oturtmamaktadır. Parsons'a (1968: 46-47) göre "bir toplumsal aktör olarak birey, bir organizmayı değil, egoyu ya da kendiliği (self)" ifade etmektedir. Bu bakış açısı, Parsons'un yapısal işlevselci yaklaşımında bireyin de failliğine ve toplumsal eylemlerindeki rasyonel tercihlerine kapı aralamaktadır. ${ }^{3}$

Parsons'un sistem kuramı ve kuramın genel hatları açısından bütünleşik afet yönetiminde toplumsal aktörlerin rolü ve işlevine dair sosyolojik bir perspektif geliştirilebilir. Şöyle ki, bütünleşik afet yönetimi hem afet öncesi hem de afet sonrası aşamaları içermesi ve toplumun topyekûn dahil olduğu bir süreç olması dolayısıyla toplumsal sisteme ve yapıya yönelik bir müdahaleye işaret etmektedir. Buna bağlı olarak, sistem kuramındaki toplumsal aksiyon hali, bütünleşik afet yönetiminin her bir aşamasında aranan ve/ya uygulanan bir duruma vurgu yapar. Öte yandan bütünleşik afet yönetimindeki temel hedefin toplumsal yaşantının afet öncesi dönemdeki gibi tesisi ve sonraki afetlere hazırlık olduğu gerçeğinden hareketle sistemin öğeleri arasında bir süreklilik örüntüsü kurulduğu da söylenebilir. Özellikle afetin yarattığı ve yaratacağ1 tahribata karşı bütünleşik bir afet yönetimi sistem içerisinde yeniden uyumu sağlamayı amaçlayan bir anlayışa işaret eder.

Sosyal sistem teorisinde gömülü olan değer, norm ve roller bütünleşik afet yönetiminde toplumsal aktörlerin afetle mücadele eylemine referans noktası sağlaması açısından ele alınabilir.

\footnotetext{
${ }^{3}$ Ancak Parsons'ın sistem kuramına yönelik eleştirilerden biri, bireyin failliğinin ancak toplumsal sistemin ve yapının öngördüğü mekanizmalar üzerinden ş̧ekillenmesidir. Poloma (1993: 165), Parsons'un kuramında bireyin failliği konusunu yorumlarken şu ifadeleri kullanır: "Kadınlar ve erkekler kendi eylemlerinde rasyoneldir, fakat onların eylemleri toplumsal normların içselleștirilmesi ile kontrol edilebilir... Parsons'un eylemdeki seçenek görüşü yapısal olarak yaratılan seçeneklerden oluşur". Bu açıdan, çalışmanın temel konusu olan bütünleşik afet yönetimi süreci incelenirken, bireyin afet yönetimine katkısının Parsons'cu manada karşılığı, ancak afet yönetimi ile ilgili toplumsal süreçlerin bireyler tarafından benimsenmesi ve uygulamaya konulması yönündedir.
} 
Afetlerin toplumsal yapıya zarar vermesine (ya da verme ihtimaline) karşılık hem değer, norm ve rollerden kaynaklı bir mücadele ortaya çıkması hem de afet sebebiyle tahribata uğrayan norm, değer ve rollerin yeniden tesisi bütünleşik bir afet yönetiminin olmazsa olmazlarındandır. Bununla bağlantılı olarak değer, rol ve normlar aracılığ ile sistemin, diğer bir ifade ile zarar gören toplumsal kurumların devamlılığı ve işlevselliği her bir toplumsal aktörün katılımı ile sağlanmaya çalışı1ır.

Afet riski ve tehlikesi ile mücadeleyi de kapsayan bütünleşik afet yönetimi, bu yönüyle toplumsal yapıya gelecek zararları önlemek adına refleks geliştiren ve bu hedefle kurgulanan toplumsal sistemin çıktılarıyla paralellik göstermektedir. Sosyal sistem teorisindeki amaca ulaşma, bütünleşme ve örüntü sürdürme aşamaları, bütünleşik afet yönetimi konusu baz alındığında her bir aşama açısından zengin veriler sunar. Örneğin müdahale aşaması, acil durum ve kriz anının bir an önce aşılmasını ve gündelik hayata (ya da pandemi sonrasının popüler ifadesiyle normalleşmeye) dönmek adına iyileştirme aşamasına geçilmesini amaçlar. Bu noktada sistemin bir parçası olan toplumsal kurumlar ve aktörlerin afetin zararlarını azaltma amacıyla bir araya gelmesi, bütünleşme ve birliktelik kavramları ışığında değerlendirilebilir. Öte yandan afet sonrası dönemde ya da afet öncesi aşamalarda bütünleşik afet yönetiminin gerektirdiği ve belli kurallara/referans noktalarına sahip olan eylemler, sistem kuramındaki örüntü sürdürme konusu kapsamında değerlendirilebilir. Her bir afet yönetim adımı, belli başlı kurallara bağlıdır ve bu kuralların olabildiğince kamusallaştırılması ile başarıya ulaşma ihtimali artmaktadır. Özetle, sosyal sistem teorisinin amaca ulaşma, bütünleşme ve örüntü sürdürme gibi çıtılarının, bütünleşik afet yönetiminin her bir aşamasında gözlenmesi mümkündür.

Sistem teorisi sosyal bilimlerde, özelde sosyolojide yalnızca Parsons'un sunduğu katkıyla sınırlı değildir. Parsons'tan sonra Niklas Luhmann ve diğer bazı teorisyenler, hem Parsons'un mirası üzerine argümanlar üretmiş hem de onun kuramını eleştirerek bireyin failliğini merkeze alan (actor-oriented) sistem teorileri geliştirmiştir (Schwanitz, 1995: 145; Burns, 2007: 3). Ancak mevcut çalışmanın sınırları dolayısıyla bu bölümde yalnızca Parsons'un sistem kuramına temas edilmiş ve bütünleşik afet yönetimine dair genel bir sosyolojik bakış açısı, sosyolojideki ilk sistem kuramı temsillerinden biri olan Parsons'cu bir bakış açısıyla ortaya konulmaya çalışılmıştır. Ayrıca bütünleşik afet yönetimindeki sosyolojik arka planı en genel haliyle gerekçelendirecek bazı temel kavramlar açısından sistem kuramının bir çatı işlevi gördüğü de belirtilmelidir. $\mathrm{Bu}$ çatıdan hareketle aşağıda sosyolojinin bazı kurucu isimlerinin üzerinde durduğu ya da bizzat ortaya attığı kavramlar, bütünleşik afet yönetiminin sosyolojik arka planını anlama hedefiyle ele alınmıştır.

\subsection{Afetler Karşısında Kolektif Bilinç ve (Organik) Dayanışma}

Sosyolojinin kurucularından Emile Durkheim'ın toplumsal yaşantının temeline oturttuğu kolektif bilinç ve modern toplumların örgütlenme modeli olarak sunduğu organik dayanışma, bütünleşik afet yönetiminin sosyolojik arka planını besleyen temel kavramlar arasındadır.

Çeşitli argümanların ve tanımların 1şı̆̆ında kolektif bilinç, bireylerin toplumsal bir aradalığını ve toplumsal kurumların devamlılığını sağlayan, kültürün ve normların sonraki nesillere aktarımını sağlayan ve üyelerinin topluma işlevsel bir hedefle katılımını ön gören bir alg1 ve eylem tarzı olarak açıklanabilir (Durkheim, 1984: 39; Wortmann, 2007: 581-582; Swingewood, 1991: 113). Kolektif bilinç, bireyde "dışsal olarak" var olmaktadır ve inanç, norm, gelenek, öğreti, fikir ve değerler aracılı̆̆ i ile içselleştirilir (Turner, 2005: 699-700). ${ }^{4}$

Durkheim'den etkilenen Parsons'un sistem kuramında olduğu gibi, kolektif bilinçte de yapının öncelendiği görülmektedir. Durkheim'ın temel sosyolojik teorisinin bir uzanımı olarak

\footnotetext{
${ }^{4}$ Çalışmanın odağı olan klasik sosyolojinin kapsamına girmese de sosyal sermaye kavramı afet yönetimi açısından birtakım veriler sunmaktadır. En basit haliyle birey açısından toplumsal normlar, katılım, güven ve dayanışma ağları üzerine kurulu bir "sermayeyi" ifade eden (Coleman, 1988: 96) ve sivil toplumu da merkezine alan (Dalzier, Saunders ve Saunders, 2018) bu kavram, özellikle afet sonrası yönetim aşamalarında afetzedelerin toplumsal yaşama yeniden intibakı açısından işlevsel bir arka plana sahiptir (Nakagawa ve Shaw, 2004; Cox ve Perry, 2011).
} 
birey, gündelik yaşantısını toplumun beklentilerinden soyutlayarak sürdüremez, hatta her bir davranışı kolektif bilicin kendisine sunduğu/dayattığı dışsal etkiye bağlıdır (Burns ve Engdahl, 1998: 68-70). Bireyin davranışlarına etki etmesinin ötesinde, kolektif bilinç işlevselci açıdan hem bireyin toplumsal fayda temelli yönelimlerini belirlemekte hem de toplum içerisinde meydana gelen sorun ya da aksaklıklar karşısında bunları telafi etmek adına bir hareket noktası olmaktadır.

Kolektif bilinç kavramının gelişiminde Durkheim'ın mekanik dayanışma olarak nitelediği bir toplumsal örgütlenme biçiminin etkisi mevcuttur. Üyelerinin birbiriyle benzer kültürel arka plana ve beklentilere sebep olduğu ve yapılan/ekonomik aktivitenin benzer formlarla ortaya çıktığı geleneksel toplumlarda benzer davranış kalıpları ortaya çıkmaktadır (Schiermer, 2014: 65, 67). Ancak modern toplumlarda nüfusun artış1, kentleşme, üretimin ve ekonomik işleyişin çeşitlenmesi ve bireyselliğin kapısını aralayan diğer birçok faktörün etkisi ile kolektif bilinçte aşınmalar meydana gelmektedir (Müller, 1994: 79). Bilhassa 19. yüzyılın sonunda Bat1 Avrupa toplumlarında etkisini hissettiren bu aşınma ve bundan kaynaklı anomi hali, Durkheim sosyolojisinde organik dayanışma kavramının gelişmesine vesile olan temel etmen olarak göze çarpmaktadır. Zira Dukheim'a göre modern toplumlarda iş bölümünün sağlanamaması, toplumsal çözülmenin yaşandığ 1 bir anomi haline işaret etmektedir ve ancak "nerede organik dayanışmaya rastlanırsa, orada işlevlerin karşılıklı ilişkilerini belirleyen yeterince geliştirilmiş bir düzenlemeye ulaşılmaktadır" (Durkheim, 1935'ten akt. Olsen, 1965: 39, 42). Tam da bu düzenlemenin yokluğu anominin başlangıcını temsil etmektedir. Dolayısıyla, yeni türden bir toplumsal birliktelik adına ya da bunun gözlemi sonucunda Durkheim, toplumda farklılaşan bileşenlerin birbirlerine olan (ya da olması gereken) bağını, her uzmanlık alanının ve meslek dalının işlevsel olarak dahil olduğu organik dayanışma kavramıyla açıklamıştır (Merton, 1994: 18). Organik dayanışma, ortaya çıkışı itibariyle kolektif bilincin (ya da mekanik dayanışma modelinin) modern bir telafisi gibi görülse de aslında yine ortak bir toplumsal şuura ve bunun yeniden tesisine vurgu yapmaktadır. $\mathrm{Bu}$ beklenti, toplumu ilgilendiren her meselede farklı uzmanlık alanlarının devreye girmesini ve gerektiği takdirde toplumsal telafi mekanizmalarının bu yolla işlerlik kazanmasını ön görmektedir.

Yukarıdaki argümanlar ışığında kolektif bilinç ve organik dayanışmanın bütünleşik afet yönetimindeki önemini birkaç temel noktada incelemek mümkündür. İlk etapta kolektif bilinç kavramına değinmek gerekirse, afet öncesi, afet esnası ve afet sonrası aşamaların yönetiminde toplumsal kurumlar ve aktörler arasında ortak bir bilinç ve buna bağlı eylem gerçekleştirilmesi, kolektif bilincin bir yansıması olarak görülebilir. Örneğin bir yangın anında evi ya da aracı yangından etkilenme ihtimali olmaksızın bir bireyin eline yangın tüpü alarak herhangi bir karşılık beklemeksizin alevlere müdahale etmesi, bazı temel insani ve toplumsal değerlerin o bireyde vücut bulduğunu ve toplumun diğer üyelerinin can ve mal güvenliği adına bir "müdahale"de bulunulabileceği gerçeğini ortaya koymaktadır. Buradaki odak nokta, bir birey olarak farklı bir insana yardımcı olmak değil, paylaşılan kolektif bilinç aracılığıyla toplumsal yaşamı sekteye uğratacak bir acil duruma ya da afete müdahale etmektir. Benzer örnekler afet öncesi yönetim aşamaları için de çoğaltılabilir. Tam da bu noktada Durkheim'in kolektif bilinçten kaynaklı ve bizzat toplumsal yaşamın sürdürülmesine yönelik toplum üyeleri tarafindan içselleştirildiği varsayılan bir ahlak anlayışı ortaya konabilir. Toplumu canlı bir organizma olarak ele alan Durkheim, bu organizmanın ve alt bileşenlerinin işlevlerini yerine getirebilmesini olgu ve değer çatısında inceler, kolektif bilincin oluşturduğu olguların ve değerlerin toplumun yararına bir ahlak ortaya koyduğunu söyler (Durkheim, 1984: 78). Bu durum, afet yönetim süreçlerinde bireyin toplum ve toplumun diğer üyeleri açısından alması gereken alturist pozisyonu bir ahlak temelinde gerekçelendirir. Bireyi harekete geçirici ve kolektif bilinçle bağlantılı bir ahlak nosyonunun eksikliği durumunda "organizma"nın sağlıklı işleyişi mümkün olmayacaktır. Diğer bir ifadeyle, afet yönetim süreçlerinin gerek afet öncesi gerekse afet sonrası dönemde toplum temelli bir ahlaka, bireylerin ötekini dikkate aldığı türden bir ahlaka ihtiyaç olduğu iddia edilebilir.

İkinci olarak, kolektif bilincin bireylerde dışsal olarak var olması ve bireyi toplum lehine eyleme zorlaması, toplumsal hayata yeniden dönüş ve sonraki afetlerde toplumun daha az zarar görmesi gibi hedeflere sahip olan bütünleşik afet yönetiminde bu kavramı hayati bir konuma taşımaktadır. Zira bütünleşik afet yönetiminde kamu kurumları, sivil toplum örgütleri ve 
vatandaşlar tarafından geliştirilmesi beklenen afet farkındalığı ve afetle mücadele dinamiği, ortak bir bilinçlilik haline vurgu yapmaktadır. Kolektif bilinçte bireyin topluma işlevsel bir hedefle katılım göstermesi, bütünleşik afet yönetiminde bireylerin afet yönetimi aşamalarında işlevsel bir hedefle sorumluluk alması olarak okunabilir. Sonuç olarak kolektif bilinç, daha çok geleneksel toplumlardaki sosyal yapı ve birey arasındaki örgütlenme, algılayış ve eylem biçimlerine vurgu yapıyor olsa da günümüzde de bireyler açısından bir referans ve meşruiyet noktası olmakta, ortak duygu ve düşünceler açısından bireyleri tetikleyebilmekte ve bu yönüyle bütünleşik afet yönetiminin her bir aşaması, aktörü ve kurumu açısından anlamlı karşılıklar bulabilmektedir.

Modern toplumlarda kolektif bilinç kavramının yerine ya da bu kavram doğrultusunda kullanılan organik dayanışma ${ }^{5}$ ise bütünleşik afet yönetimi aşamalarında gözlenmesi mümkün tecrübeleri doğurmaktadır. Afet öncesi, afet esnası ve sonrasında afetin etkilerini azaltmak ve bir sonraki muhtemel afet(ler)e hazırlıklı olmak adına farklı işlevlere sahip toplumsal aktörler ve kurumlar, farklı iş kolları üzerinden afetle mücadele etmektedir. Bu durum, modern toplumsal yaşantıdaki maddi ve manevi kültürel öğelerin ve ekonomik işleyişin meslekler ve uğraşı alanları üzerinden çeşitlenmesinden kaynaklanmaktadır. Afetlerle öncesi ve sonrası ile mücadele edilebileceğinin fark edilmesi, işte bu farklı meslek ve uğraşı alanlarının afetler karşısında (ve kolektif bir bilinç ile) örgütlenmesi sonucunu doğurmuştur. Örneğin deprem tehlikesi karşısında bütünleşik bir afet yönetimini benimseyen bir toplumsal organizasyonda mühendisler ve mimarlar aracılığı ile binaların dayanıklılığını ölçülür ve tehlike arz eden binalar, gerektiği takdirde hukukçuların kararı ve kolluk kuvvetlerinin müdahalesi ile boşaltılır. Diğer yandan okullarda öğretmenler ve idareciler tarafından deprem esnasında binanın nasıl tahliye edilmesi gerektiğine dair öğrenciler bilgilendirilir. Deprem sonrası toplanma alanları belediye görevlileri ve AFAD ekipleri tarafından belirlenir ve e-devlet sistemi üzerinden ilgili yazılımcılar aracıllğg ile vatandaşlara duyurulur. Bu arada elektrik, su ve doğalgaz altyapısının belli bir şiddetteki depreme kadar sağlam kalabilmesi için ilgili meslek dallarının temsilcileri bu yönde sağlamlaştırma ya da restorasyon çalışmaları yürütür. Aynı anda kamu kurumlarında istihdam edilen psikolog, sosyal hizmet uzman1, sivil savunma uzmanı gibi görevlere sahip bireyler depremlere hazırlıklı olma, deprem anında ve sonrasında nasıl hareket edilmesi gerektiği gibi konularda çeşitli bilgilendirme toplantılarına dahil olur ve/ya ulusal kanallarda sunulacak kamu spotlarında kullanılmak üzere içerik hazırlar. Daha farklı meslek gruplarının bütünleşik afet yönetiminin diğer aşamalarındaki dahline dair örnekler çoğaltılabilir. Tüm örneklerdeki ortak nokta, farklı meslek gruplarındaki insanların bir dayanışma hali ile afeti önleme, hafifletme ya da afetin zararlarını azaltma amacıyla hareket etmeleridir. Bu durum, bütünleşik afet yönetimi açısından farkındalığın da ötesinde bir dayanışma ve eylem halinin ortaya çıktı̆̆ını göstermektedir. Bunun ardında yatan temel sebeplerden biri de yine sosyolojinin kurucularından Durkheim'ın (1984) modern toplumların örgütlenme biçiminde büyük bir önem atfettiği iş bölümünün (division of labour) toplumsal aktörler tarafından benimsenen ve uygulanan bir süreç olmasıdır. İş bölümü, yarattığı organik dayanışma ve beslendiği kolektif bilinç aracılığı ile bütünleşik afet yönetimi açısından kritik bir öneme sahiptir. Bu önemin daha iyi anlaşılabilmesi açısından kolektif bilincin ya da organik dayanışma pratiklerinin var olmadığ bir bütünleşik afet yönetimini düşünmenin mümkün olmadığı akla getirilebilir. Bir afet sonrasında ya da öncesinde insanların salt bireysel çıkarlarına göre hareket etmesi, organik dayanışma pratiklerini yerine getirmeyerek her bir bireyin yalnızca kendi imkanlarıyla afet yönetimine dahil olması ne kolay kolay gözlenebilecek bir durumdur ne de bu çabalar, modern anlamda bir afet yönetimine işaret etmektedir. Tüm bu sebeplerden ötürü bütünleşik afet yönetimi süreci, sosyolojik olarak kolektif bilinç ve organik dayanışmaya dair veriler sunmasının ötesinde, bu iki kavramdan bağımsız düşünülemeyecek algı, eylem ve toplumsallık uzanımlarına sahiptir. Diğer bir ifadeyle, hangi afete yönelik bütünleşik bir yönetim süreci gözlenirse gözlensin, kolektif bilinç ve organik dayanışmanın çıktılarına mutlak surette rastlanılacaktır.

\footnotetext{
5 Organik dayanışma, modern sanayi toplumlarında uzmanlaşma ve bireyselleşme dolayısıyla zayıfladığı düşünülen kolektif bilinci tamamlama ya da bu tür toplumlarda ortaya çıkan kolektif otoriteye bir gerekçe oluşturma açısından işlevsel bir arka planı mevcuttur. Bu konuda Wallace ve Wolf'un (2005: 45-49) çalışmasında kapsamlı bir açıklama mevcuttur.
} 


\subsection{Afet Döngüsünde Rasyonalite ve Uzmanlaşma}

Geleneksel toplumlardan modern toplumlara geçişin "fotoğrafını çeken" ve bu değişimi teoriler 1şığında açıklamaya çalışan kurucu sosyologlar, yeni türden bir toplumsallığa özgü kavramlar ortaya koymuştur. Rasyonalite ya da rasyonelleşme bu kavramlardan biridir. Sosyolojide daha çok Max Weber ile etkisini hissettiren bu kavram, en genel haliyle toplumsal ve ekonomik yaşantının tesisinde temel zihni ve pratik referansların akıl ve akılcı düşünme biçimi olduğunu iddia eder (Weber, 1968'den akt. Ritzer, 1975: 628). Rasyonalizm olarak adlandırılan bu düşünce toplumsal kurumların işleyişinde ve bireylerin toplumsal eylemlerinde akla dayalı verilerden hareketi öngörür. Karmaşıklaşan ve organik dayanışmanın hâkim olduğu modern toplumlarda bu karmaşadan kurtulabilmek, hesaplanabilir ve makul neden sonuç ilişkilerine dayanan eylemlerle mümkündür. Örneğin Weber'in modern toplumların yönetim şeklini açıklamada kullandığı yasal/ussal otorite, meşruiyetini akılsal çıkarımlardan ve bu çıkarımların yazılı yansımaları olan kanun ve kurallardan almaktadır (Weber, 2019: 54-56; Beetham, 1991: 38). Geleneksel otoritede var olan din bağlamlı kutsallar, modernleşme ile yerini belki de yeni bir kutsal olarak akıl ve mantıksal çıkarım merkezli rasyonel yasalara bırakmıştır.

Uzmanlaşma ise önceki bölümde tartışılan toplumsal iş bölümünün bir gerekçesi, aynı zamanda sonucu olarak sosyolojide ortaya çıkmıştır. Modernleşme ile sosyoekonomik yaşantının çok çeşitli meslek ve uğraşı alanları üzerinden kurulması, kaynakların etkin kullanımı ve toplumun üyeleri arasında dağıtımı için uzmanlık gerektiren bilginin dolaşımını gündeme getirmektedir (Alexander, 1992: 182). Daha basit bir ifadeyle bireylerin sosyoekonomik yaşantıda yer edinebilmesi, toplumun diğer üyelerinin de faydasını gözeten bir dayanışma ve bu dayanışmaya temel oluşturan uzmanlaşma ile mümkün olmaktadır. Tam da bu noktada uzmanlaşmanın, rasyonel bir eylem olarak birey-toplum ilişkisinin seyrini belirlediğini söylemek gereklidir. Zira her bir alanda uzmanlık akılcı algı, tasarım ve eylemlerle mümkündür.

Rasyonelleşme ve uzmanlaşma konusu, günümüz küresel toplumunda çok daha geniş bir etki alanına kavuşmaktadır. Bu bağlamda, kurucu sosyologların toplumsal yaşantı için yorumladığı bu kavramların, toplumsal sistem, yapı ve işlev konularına kapı aralayan afet ve afetle mücadelede somut karşılıkları olduğu söylenebilir. Çalışmanın temel konusu olan bütünleşik afet yönetimi çerçevesinden bakılacak olursa,

a) çeşitlenen ve ne zaman nerede ortaya çıkacağ 1 belli olmayan afetlere karş1 alınacak tedbirlerin,

b) farklı ölçeklerde tahribata sebep olan afetler sonrasında atılacak müdahale ve iyileştirme adımlarının rasyonel ve uzmanlık gerektiren bilgiyle analizi ve tatbiki önem arz etmektedir.

Bütünleşik afet yönetimindeki etki analizi, tahmin, erken uyarı, engelleme, müdahale, iyileştirme ve hazırlıklı olma aşamalarının her biri rasyonel hesapları, analizleri ve öngörüleri içermektedir. Aynı zamanda bu hesap ve analizler, uzman bilgisini gerektirmekte ya da ortaya koymaktadır. Tekrar deprem örneğini hatırlamak gerekirse, bütünleşik bir deprem yönetiminin hangi aşamasında hangi rasyonel ve uzmanlık gerektiren bilgiye ve eyleme ihtiyaç duyulduğu aşağıdaki tabloda işlenen haliyle özetlenebilir:

Tablo 1. Bütünleşik Bir Deprem Yönetiminde Rasyonalite, Uzmanlaşma ve İş Bölümü Görünümleri

\begin{tabular}{|l|l|l|}
\hline Aşama & \multicolumn{1}{|c|}{ Rasyonalite } & \multicolumn{1}{c|}{ Uzmanlaşma ve İş Bölümü } \\
\hline $\begin{array}{l}\text { Hazırlıklı } \\
\text { Olma }\end{array}$ & $\begin{array}{l}\text { Fiziki ve mental olarak toplumun } \\
\text { depreme hazırlılı olması için } \\
\text { atılacak akılcı adımlar ve afet } \\
\text { sonrasında nasıl hareket } \\
\text { edileceğinin önceden planlanması. }\end{array}$ & $\begin{array}{l}\text { Farklı disiplinlerden uzmanların } \\
\text { depreme hazırlıkta toplumu } \\
\text { bilgilendirmesi ve atılacak } \\
\text { rasyonel adımları belirleyerek } \\
\text { toplumsal aktörlerin bu adımlara } \\
\text { aşina kilınması }\end{array}$ \\
\hline Tahmin & $\begin{array}{l}\text { Deprem konusunda kümülatif } \\
\text { bilimsel bilginin akılcı yorumu ve }\end{array}$ & $\begin{array}{l}\text { Başta yer bilimciler olmak üzere } \\
\text { fiziki olarak deprem konusu }\end{array}$ \\
\hline
\end{tabular}




\begin{tabular}{|c|c|c|}
\hline & $\begin{array}{l}\text { depremin meydana geleceği } \\
\text { muhtemel tarih aralığına ilişkin } \\
\text { akılcı tahminler. }\end{array}$ & $\begin{array}{l}\text { üzerinde çalışmalar yürüten } \\
\text { uzmanların, beklenen depremin } \\
\text { tarih aralığına ilişkin tahminde } \\
\text { bulunması. }\end{array}$ \\
\hline $\begin{array}{l}\text { Erken } \\
\text { Uyarı }\end{array}$ & $\begin{array}{l}\text { Deprem erken uyarı sistemlerinin } \\
\text { üretimi, kurulumu ve uyarının } \\
\text { devreye girmesi sonrasında } \\
\text { insanlar tarafından binaların } \\
\text { tahliyesinin akılcı bir şekilde } \\
\text { planlanması ve bunun ilanı. }\end{array}$ & $\begin{array}{l}\text { Erken uyarı sisteminin teknik } \\
\text { uzmanlarca üretimi ve test } \\
\text { edilmesi. }\end{array}$ \\
\hline Engelleme & $\begin{array}{l}\text { Depremin fiziki olarak } \\
\text { engellenmesi mümkün olmasa da } \\
\text { bir afet haline gelişinin } \\
\text { engellenmesi adına binaların ya } \\
\text { da diğer türden meskenlerin } \\
\text { sağlamlığının kontrolü, belli bir } \\
\text { şiddetteki depremde yıkılması } \\
\text { olası hasarlı binaların tahliyesi. }\end{array}$ & $\begin{array}{l}\text { Binaların ve zeminlerin } \\
\text { uzmanlar tarafından etüdü ve } \\
\text { dayanıksız binaların } \\
\text { tahliye/yıkım kararının } \\
\text { onanması. }\end{array}$ \\
\hline Etki Analizi & $\begin{array}{l}\text { Depremin hemen ardından hasar } \\
\text { tespiti, hayatı tehdit eden } \\
\text { unsurların belirlenmesi ve } \\
\text { depreme müdahalede sağlıklı } \\
\text { metotların belirlenmesi için akılcı } \\
\text { bir planlama. }\end{array}$ & $\begin{array}{l}\text { Depremin yarattığ jeolojik, } \\
\text { psikolojik, biyolojik etkinin bu } \\
\text { alandaki uzmanlar tarafindan } \\
\text { değerlendirilmesi ve } \\
\text { müdahalede bulunacak } \\
\text { uzmanlara mevcut etkiye dair } \\
\text { bilgi verilmesi. }\end{array}$ \\
\hline Müdahale & $\begin{array}{l}\text { Deprem sonrasında yıkılan } \\
\text { binalarda kaç kişinin olduğunun, } \\
\text { yıkımın şekline göre göçük } \\
\text { altında kalanlara nasıl } \\
\text { ulaşılacağının analizi ve ilgili } \\
\text { hesaplamalar sonrası afetzedelere } \\
\text { ulaşmak adına harekete geçilmesi, } \\
\text { hasar görmese de konutuna } \\
\text { giremeyenler için temel yaşam } \\
\text { malzemelerinin temini için } \\
\text { atılacak adımlar. }\end{array}$ & $\begin{array}{l}\text { Profesyonel ve uzman arama } \\
\text { kurtarma ekiplerinin göçük } \\
\text { altında kalan binalara } \\
\text { müdahalesi, afet uzmanları } \\
\text { tarafından göçük altında } \\
\text { kalmayan afetzedeler için } \\
\text { ihtiyaç tespitinin yapılarak } \\
\text { yaşamsal malzemelerin bölgeye } \\
\text { getirilmesinin sağlanması. }\end{array}$ \\
\hline İyileştirme & $\begin{array}{l}\text { Acil durum ve kriz anının sona } \\
\text { ermesini takiben depremzedelerin } \\
\text { toplumsal hayata yeniden intibakı } \\
\text { için atılacak adımları hesaplama } \\
\text { ve uygulamaya koyma, zarar } \\
\text { gören alt yapının rasyonel } \\
\text { hesaplamalarla yeniden tesisi. }\end{array}$ & $\begin{array}{l}\text { Afetzedelerin fiziki ya da } \\
\text { psikolojik travmalarını tedavi } \\
\text { etmek adına hekimlerin ya da } \\
\text { psikologların uzmanlık } \\
\text { bilgisinden faydalanılması, alt } \\
\text { yapının onarımı için ilgili } \\
\text { uzmanların teknik bilgisinden } \\
\text { faydalanılması. }\end{array}$ \\
\hline Hafifletme & $\begin{array}{l}\text { Risk analizleri, } \\
\text { senaryoları ve hesaplamalar } \\
\text { doğrultusunda bir sonraki } \\
\text { depremde hangi tür zararlar } \\
\text { doğacağını öngörüp buna göre } \\
\text { tedbirler alma (Hazırlıklı olma } \\
\text { adımı ile benzerlik gösterse de } \\
\text { hafifletme daha dar bir } \\
\text { çerçevedeyken diğeri afet sonrası } \\
\text { eylem planını da içermesi } \\
\text { dolayısıyla daha geniş bir } \\
\text { uygulama alanına sahiptir) }\end{array}$ & $\begin{array}{l}\text { Depremin muhtemel fiziki, } \\
\text { fiziksel ve ruhsal zararlarını } \\
\text { azaltacak her türlü adımda yetkin } \\
\text { olan uzmanların teknik } \\
\text { bilgisinden faydalanılması. } \\
\text { Binalara ilişkin tasarrufta yerel } \\
\text { ya da merkezi yönetimlerin } \\
\text { uzmanları ile koordine halinde } \\
\text { olunması. }\end{array}$ \\
\hline
\end{tabular}


Yukarıdaki tabloda olası bir depremin bütünleşik afet yönetimi çerçevesinde ele alınışında muhtemel rasyonel/akılcı yaklaşımlar ve bunun uzmanlık bilgisi ile olan ilişkisi incelenmiştir. Her bir aşamada planlama, ölçme, profesyonel yaklaşım, verilerden yola çıkarak akıl yürütme ya da ön görüde bulunma gibi konular ortaya çıkmaktadır. Ayrıca her bir aşamada uzmanlaşmanın ve uzman bilgisinin önemi gözlenebilir. Bu durum, diğer afetler için de geçerlidir. Bu sebeple rasyonalite ve uzmanlaşmanın, tıpk1 kolektif bilinç ve organik dayanışmada olduğu gibi bütünleşik afet yönetimi açısından adeta görmezden gelinemez birer yaklaşım ve eylem tarzı olduğu belirtilmelidir. ${ }^{6}$

\subsection{Bürokrasi ve Bütünleșik Afet Yönetimi}

Modern dönemle birlikte toplumsal yaşamda ortaya çıkan organik dayanışma, uzmanlaşma ve rasyonelleşme gibi süreçler günümüz toplumlarının tecrübe ettiği bürokrasi olgusunu git gide güçlendirmektedir. Weber'in sosyolojik uğraşısında önemli bir yere sahip olan bürokrasi, bizzat kendisi tarafından makama bağlı bir güç, örgütlenmeden gücünü alan kurallar, organizasyonel eylemi belirleyen disiplin sistemi, kuralların kodlanmış ve standardize edilmiş hali, meşruiyetin sınırlarını belirleyen kural ve eylemler, görevlerin işlevsel paylaşımı, otoritenin hiyerarşik temsili, haklar, sorumluluklar, görevler ve zorunlulukların rasyonel belirlenimi, kıdeme ve liyakate göre oluşan hiyerarşi gibi içerikler (Clegg, 2007: 376-377) açısından ele alınmıştır.

Modern toplumlarda gerek devlet kurumlarında gerekse özel sektörde sosyoekonomik yaşantının sürdürülebilmesi ve bireylerin toplumsal kurumlara dahil oluşu, bürokrasinin varlığı ile mümkün olmaktadır. Zira rasyonel bir yaklaşımla işlerlik kazanan modern toplumlarda kayıt tutma, şeffaflık ve hesap verilebilirlik olguları adeta bir zorunluluktur (Balc1, 2005: 330). Bireyin doğumundan ölümüne kadar geçen süre içerisinde gerek aldığı eğitim ve sağlık hizmetleri gerekse iş yaşamındaki varlığı sürekli olarak kayıt altına alınmakta, ayrıca siyaset kurumuyla olan asgari bağı dahi yine kayıt ve resmiyet içeren seçme ve/ya seçilme süreçleri ile kurulmaktadır. Bunların yanı sıra bireyler de toplumsal organizasyona dahil olduğu hemen her aşamada bu kayıt, hesap verilebilirlik ve şeffaflık konusuyla muhatap olmaktadır.

Bireyin daha çok formel alandaki toplumsal etkileşimini sürdürürken karşı karşıya kaldığı bürokrasinin, modern toplum açısından adeta bir zorunluluk haline geldiğini söylemek yanlış olmayacaktır. Öte yandan, tekrar hatırlamak gerekirse toplumsal yaşantının ve toplumsal değişmenin seyrine ilişkin hem kamu kurumlarının hem sivil alanın hem de bireylerin alacağı inisiyatifin bürokratik bir kanaldan beslenmesi de kaçınılmaz olmaktadır. Bu sebeple, kitlesel yıkım, kayıp ve zararlara sebep olan, bu yolla toplumsal sistemi ve kurumları etkileyen, bunları değiştiren ve dönüştüren afetlerle mücadelenin bürokrasiden bağımsız olmadığı ifade edilebilir.

Bütünleşik afet yönetimi açısından bakıldığında, toplumsal kurumların ve aktörlerin bu sürece dahli ve yönetim süreçlerinin en ince ayrıntısına kadar seyri bürokratik bir resmiyete, düzene ve işleyişe sahiptir. Bu işleyiş ve kurallar, bütünleşik perspektif açısından hem afet öncesinde hem de afet sonrasında etkin kılınır ve gerekli görüldüğ̈ durumlarda revize edilir.

Çalışmada sıklıkla başvurulan deprem örneğinden devam edilecek olursa, büyük çaplı yıkımlara sebep olan bir depreme müdahale edilirken hangi bürokratik kurumun hangi yasa ya da yönetmeliklere istinaden hangi kamu görevlileri aracılığıyla yetkili ve koordine edici konumda olduğu önceden

\footnotetext{
${ }^{6}$ Yine klasik sosyoloji çatısında değerlendirilmesi mümkün olmasa da başta Beck (1992) ve Giddens (1999) olmak üzere çağdaş sosyologların odaklandığı risk toplumu kavramının, bütünleşik afet yönetimi ile neredeyse ontolojik bir bağa sahip olduğu iddia edilebilir. Bütünleşik afet yönetiminin gündemindeki temel hedefler olan afetlere hazırlıklı olma, afetler karşısında dirençli bir toplum yaratma ve afetin zararlarını minimuma indirme, toplumların her an bir afet riski ile karşı karşıya olduğu ya da özellikle yapay afetler söz konusu olduğunda bu riski sürekli olarak ürettiği varsayımından hareket eder. Bu açıdan geç modern dönemde (ya da risk toplumunda) bireylerin her an karşı karşıya kaldığı ekonomik, hukuki, eğitimsel, vb. riskler daha geniş bir çerçevede toplumların ya da toplulukların karşı karşıya kaldığı afet riskleriyle örtüşen bir arka plana sahiptir. Diğer bir açıdan, risk toplumu bireyler açısından muhtemel olumsuzluklara karşı bir teyakkuz halini ifade ederken, bütünleşik afet yönetimi de hem geç modern toplumun hem de afetlerin yarattığı/yaratması muhtemel risklere karşı bir teyakkuz haline işaret etmektedir.
} 
belirlenmiştir. Bu yetki ve koordinasyon, yine kamuya açık yasalar doğrultusunda ve deprem bölgesinde oluşturulan bürokratik mercilerin (Kriz Masas1, Afet Koordinasyon Birimi, vs.) kararlariyla afete müdahale edecek sivil unsurların hareket alanını belirlemektedir. Ayrıca bu sivil unsurlar da bahsi geçen bürokratik süreçlere dahil olarak müdahalesini sürdürmektedir. Afete müdahalede yetki, sorumluluk ve inisiyatif bürokrasinin çizdiği sınırların dışına çıktığında, otorite bağlamlı sorunların vücut bulması endişesiyle herhangi bir boşluğa ya da şeffaf/yasal olmayan bir eyleme izin verilmez. Benzer durum, iyileştirme aşaması için de geçerlidir.

Bütünleşik afet yönetiminde bürokrasi, afet öncesi aşamalarda da gözlenmektedir. Yine yasalar, kararlar ve bürokratik merciler aracıllğ 1 ile afet öncesi yönetime dahil olacak aktörlerin rolleri ve sorumlulukları belirlenir. Örneğin beklenen İstanbul Depremine ilişkin olarak binalarda hasar tespit çalışmalarının yapılması, önceden rasyonel verilere göre belirlenen standartlara açısından dayanıksız olarak nitelenen binaların hukuki çerçevede tahliyesi/yıkımı ve mal sahiplerine yapılacak kira ödemeleri bürokratik şeffaflık ve meşruiyet ilkesi ile belirlenir. Dolayısıyla hak kaybına ya da mağduriyete sebep olabilecek durumlarda bireyler hukuki yollara yani rasyonel otoriteye başvurabilir. Benzer şekilde, evlerin satın alma ya da kiralanma aşamalarında yapılan deprem sigortaları da afet yönetiminde bürokratik ve yasal bir adımı içermektedir. Bu adım vatandaşların bir afet dolayısıyla maddi kaybının önüne geçmeyi, dolayısıyla bireyin sosyoekonomik yaşantısını güvence altına almayı hedefler.

Ülkelerin afetle mücadeleden sorumlu resmi birimleri, yerel yönetimler ve sivil toplum kuruluşlarının afetlere hazırlık aşamasında yürüttüğü bireysel ya da koordineli çalışmalar da bürokrasi ve şeffaflık merkezlidir. Özellikle kurumlar arası koordinasyonu sağlayacak ve depremin muhtemel etkilerini azaltmayı amaçlayan protokoller ve anlaşmalar bürokratik süreçlerin birer çıktısıdır.

Bütünleşik afet yönetiminin resmi ve işleyişsel seyrini belirleyen bürokratik adımlar afetler karşısında kolektif bilinç ve dayanışmanın rasyonel bir işleyişe dahil olmasını sağlar ve bunu yasal yollarla garanti altına alır. Her bir toplumsal aktör ve kurumun gerek afet öncesinde gerekse afet sonrasında hangi eylem alanına ve şekline tabi olacă̆ alan gönüllüler açısından dahi bu durum geçerli olmaktadır. ${ }^{7}$ Sonuç olarak modern toplumsal yaşantıya yön veren bürokrasi olgusu, toplumsal değişme ve telafi mekanizmalarının bir uygulama alanı olarak afetlerde ve afetlerle mücadelede varlığını ve etkisini hissettirmektedir.

\section{SONUÇ}

Eski çağlardan itibaren toplumların sürekli olarak karşı karşıya kaldığı ve bundan sonra da kalacağı afetler, sosyal bilimlerin, özelde sosyolojinin gündemini meşgul etmeye devam etmektedir. Afetlerin toplumsallığı, toplumsal değişmeye etkisi ve bireyin toplumsal yaşamına yönelik yıkıcı etkisi, bu meşguliyetin ardındaki temel gerekçelerden biridir.

Afetlerin insan ya da insan hatası merkezli olarak algılanışı vesilesiyle afetlerle mücadelenin de insan odaklı algılanışı ve pratiği güçlenmektedir. Bu sebeple çalışmanın temel konusu olan bütünleşik afet yönetimi, bireylerin bir araya gelerek oluşturduğu toplumlarda her bir kurumun ve aktörün sürdürülebilir bir şekilde dahil olduğu ya da olması gereken bir süreci ifade etmektedir.

Bu çalışmada, sosyolojinin bazı klasik kuram ve kavramları, bütünleşik afet yönetimi konusu bağlamında ele alınmıştır. Afetlerin hem sonrasına hem de öncesine vurgu yapıp toplumun üyelerinin kolektif bir şekilde katkı sunması beklentisini içeren bütünleşik afet yönetiminin, sosyolojinin kuruluş aşamasında ortaya çıkan kavram ve teorilerle ne kadar iç içe olduğu ortaya konulmuştur. Temel toplumsallaşma süreçlerini destekleyen kolektif bilinç, dayanışma gibi konulara ek olarak modern bir bireyin toplumsal yaşama dahlinde anahtar vazifesi gören bürokrasi ve uzmanlaşma konularının bütünleşik afet yönetimi konusunda hangi olgu, fenomen ve pratiklerle ortaya çıktığı gösterilmiştir. Rasyonalite ve toplumsal organizasyonun rasyonel bir kurgu ve araçlarla şekillendirilmesi de bütünleşik

\footnotetext{
${ }^{7}$ Ancak modern toplumlar açısından işlevsel bir arka plana sahip olan bürokrasi, bireyler açısından kimi durumlarda bu işlevini yitirebilmekte, illegal olmasa dahi yasal karşılığı olmayan durumlarda bireysel inisiyatifin önüne geçebilmektedir. Bu durum, afetlerle mücadelede bireysel ve/ya sivil inisiyatifin kimi durumlarda bürokrasinin setine takılması durumunu doğurabilmektedir. Bu durum, Weber'in rasyonel toplumlarda, yine rasyonalitenin etkisiyle ortaya çıkan bürokrasiyi tanımlarken kullandığı "demir kafes" ifadesini akla getirmektedir (Güler Aydın, 2010: 28-29).
} 
afet yönetimi ve klasik sosyoloji ilişkisi açısından bir çatı işlevi görmüştür. Bu kavramlar ve afet yönetim süreçlerindeki karşlıkları aracılığıyla çalışmada toplumsal sistem, toplumsal kurumlar, toplumsal yapı ve toplumsal işlev gibi konuların kapsamına giren örnekler sunulmuştur.

Çalışma vesilesiyle çok spesifik ve teknik bir arka plana sahip olduğu ön görülen bütünleşik afet yönetiminin, afet öncesi ve afet sonrası aşamalar incelendiğinde tıpkı gündelik hayattaki toplumsallaşma ve toplumsal düzeni sürdürme gibi hedeflerin içeriğini karşıladığ ortaya çıkmıştır. Çalışmanın temel bulgusu, günümüzde afetlerin kaynağında insana ve insan hatasına odaklanılması sonucu rasyonalitenin, kolektif bilincin, organik dayanışmanın ve uzman bilgisinin kullanımına daha fazla odaklanıldığı ve bütünleşik afet yönetiminin sosyolojik arka planında afetlere dirençli bir toplum yaratma, toplumların afetleri en az zararla atlatması ve afetlere hazırlıklı bir toplum tasarımının ön plana çıktı̆̆ıdır.

Afet sosyolojisi alanı ve afet yönetimi konusunda Türkiye'de uzun bir zamandır çalışma üretilse de bu çalışmaların sosyolojinin diğer alt alanlardaki çalışmalara nazaran "nicelik" itibariyle daha yetersiz olduğu düşünülmektedir. Genelde siyaset bilimi ve kamu yönetimi ve son zamanlarda müstakil bir bölüm olan afet ve acil durum yönetimi anabilim dallarındaki hocaların ya da lisansüstü öğrencilerin odaklandığı afet ve toplum konusu, sosyoloji anabilim dalının da bir an önce odaklanması gereken içerikler sunmaktadır. Nitekim bu çalışmada ortaya konulmaya çalışılan bütünleşik afet yönetimi ve sosyoloji arasındaki organik hatta ontolojik bağ, bir yönüyle de sosyolojinin bu alandaki çalışmaları için hem bir ipucu hem de bir yol haritası sunma iddiasındadır.

\section{KAYNAKLAR}

AFAD (2021a). Açıklamalı Afet Yönetimi Terimleri Sözlüğü/Afet. https://www.afad.gov.tr/aciklamali-afet-yonetimi-terimleri-sozlugu (Erişim Tarihi: 24.03.2021).

AFAD (2021b). Açıklamalı Afet Yönetimi Terimleri Sözlüğü/Bütünleşik Afet Yönetimi. https://www.afad.gov.tr/aciklamali-afet-yonetimi-terimleri-sozlugu (Erişim Tarihi: 24.03.2021).

Alexander, D. (2012). Disasters: Lessons Learned?, Journal of Geography and Natural Disasters, 2(1), 1-2.

Alexander, J . C. (1992). Durkheim's Problem and Differentiation Theory Today. In Hans Haferkamp and Neil J. Smelser (Eds.), Social Change and Modernity (pp. 179-205). Los Angeles, CA: University of California Press.

Balcı, A. (2005). Bürokrasi-Demokrasi İlişkisi ve Hesap Verebilirlik Yaklaşımı. Hacettepe Üniversitesi Íktisadi ve İdari Bilimler Dergisi, 23(1), 313-338.

Baltac1, A. (2019). Sosyal Sistem Kuramı ve Eğitim Örgütlerine Etkileri. Medeniyet Eğitim Araştırmaları Dergisi, 3(1), 1-19.

Bayhan, V. (2020). Afetlerin Psiko-Sosyal Etkileri ve Psiko-Sosyal Destek Uygulamaları. İslam Can (Ed.), Afet Sosyolojisi içinde (ss. 285-303). Konya: Çizgi Kitabevi.

Beck, U. (1992). Risk Society: Towards a New Modernity. London: Sage.

Beetham, D. (1991). Max Weber and the Legitimacy of the Modern State. Analyse \& Kritik, 13(1), 34-45.

Burns, T. (2007). System Theories. In George Ritzer (Ed.), The Blackwell Encyclopedia Sociology (11th Edition) (pp. 4922-4928). Oxford: Blackwell Publishing.

Burns, T., \& Engdahl, E. (1998). The Social Construction of Consciousness. Part 1: Collective Consciousness and its Socio-Cultural Foundations. Journal of Consciousness Studies, 5(1), 67-85.

Can, İ. (2020). Giriş Niyetine-Afet Sosyolojisine Alan Açma Çabası. İslam Can (Ed.), Afet Sosyolojisi içinde (ss. 15-39). Konya: Çizgi Kitabevi.

Carter, W. N. (2008). Disaster Management-A Disaster Manager's Handbook. Mandaluyong: Asian Development Bank.

Clegg, S. (2007). Bureaucracy and Public Sector Governmentality. In George Ritzer (Ed.), The Blackwell Encyclopedia Sociology (11th Edition) (p. 376-378). Oxford: Blackwell Publishing. 
Coetzee, C., \& Van Niekerk, D. (2012). Tracking the Evolution of the Disaster Management Cycle: A General System Theory Approach. Jàmbá: Journal of Disaster Risk Studies, 4(1), 1-9.

Coleman, J. S. (1988). Social Capital in the Creation of Human Capital. American Journal of Sociology, 94, 95-120.

Cox, R. S., \& Perry, K.M. (2011). Like a Fish Out of Water: Reconsidering Disaster Recovery and the Role of Place and Social Capital in Community Disaster Resilience. Am J Community Psychol. 48(3-4), 395-411.

Çakır, E., \& Artun, A. A. (2020). Türkiye'de Afete Dirençli Toplum ve Afet Eğitimi. Murat Yaman ve Erkan Çakır (Ed.), Farklı Boyutlartyla Afet Yönetimi içinde (ss. 63-83). Ankara: Nobel Yayınc1lik.

Dalziel, P., Saunders, C., \& Saunders, J. (2018). Civil Society and Social Capital. In Paul Dalziel, Caroline Saunders and Joe Saunders (Eds.), Wellbeing Economics: The Capabilities Approach to Prosperity (p. 67-87). New York: Springer

Durkheim, E. (1984). The Division of Labour in Society, with an Introduction by Lewis Coser (Translated by W. D. Halls). London: Palgrawe MacMillan.

Ekşi, A. (2016). Afet Yönetiminde Temel Etik İlkeler ve İkilemler. Zerrin Toprak Karaman ve Asuman Altay (Ed.), Bütünleşik Afet Yönetimi içinde (ss. 75-100). İzmir: İlkem Yayınc1lık.

Ergünay, O. (2005). Afet Yönetiminde İşbirliği ve Koordinasyonun Önemi. Afet Yönetiminin Temel Illkeleri içinde (ss. 1-18). Ankara: JICA Türkiye Ofisi.

Fidan, T. (2017). Talcott Parsons ve Niklas Luhmann'da Meşruiyet Düşüncesi: Örgütsel ve İşlemsel Meşruiyeti. Mehmet Akif Ersoy Üniversitesi Sosyal Bilimler Enstitüsü Dergisi, 9 (20), 265-282.

Giddens, A. (1999). Runaway World: How Globalization is Reshaping Our Lives?. London: Routledge.

Güler Aydın, D. (2010). Kapitalizmde Bireyin Sorgulanması: Yabancılaşma ve Demir Kafes. Amme Iddaresi Dergisi, 43(2), 17-32.

Günpay, O. G. (2020). Bütünleşik Afet Yönetiminde Gönüllü Çalışmalar ve Güvenlik (Yayımlanmamış Yüksek Lisans Tezi). Dokuz Eylül Üniversitesi Sosyal Bilimler Enstitüsü, İzmir.

Kadığlu, M. (2008). Modern, Bütünleşik Afet Yönetiminin Temel İlkeleri. Mikdat Kadığlu ve Emin Özdamar (Ed.), Afet Zararlarını Azaltmanın Temel İlkeleri içinde (ss. 1-34). Ankara: JICA Türkiye Ofisi.

Layder, D. (2008). Sosyal Teoriye Giriş (çev: Ümit Tatlıcan). İstanbul: Küre Yayınları.

Lindell, M. K. (2013). Disaster Studies. Current Sociology, 61(5-6), 797-825.

Malalgoda, C., Amaratunga, D., \& Haigh, R. (2014). Challenges in Creating a Disaster Resilient Built Environment. Procedia Economics and Finance, 18(2014), 736-744.

Marshall, G. (2005). Sosyoloji Sözlü̆̈̈̈ (çev. Osman Akınhay ve Derya Kömürcü). Ankara: Bilim ve Sanat.

Matthewman, S. (2015). Disasters, Risks and Revelation. London: Palgrave MacMillan.

Mayhew, L. H. (1982). Talcott Parsons on Institutions and Social Evolution. Chicago, IL: The University of Chicago Press.

Merton, R. K. (1994). Durkheim's Division of Labor in Society. Sociological Forum, 9(1), 1725.

Mishra, D., Kumar, S., \& Hassini, E. (2019). Current Trends in Disaster Management Simulation Modelling Research. Annals of Operations Research, 283, 1387-1411.

Moe, T. L., \& Pathranarakul, P. (2006). An Integrated Approach to Natural Disaster Management. Disaster Prevention and Management, 15(3), 396-413.

Müller, H. P. (1994). Social Differentiation and Organic Solidarity: The Division of Labor Revisited. Sociological Forum, 9(1), 73-86.

Nakagawa, Y., \& Shaw, R. (2004). Social Capital: A Missing Link to Disaster Recovery. 
International Journal of Mass Emergencies and Disasters, 22(1), 5-34

Olsen, M. E. (1965). Durkheim's Two Concepts of Anomie. The Sociological Quarterly, 6(1), $37-44$.

Özdikmen, T. (2020). Afet ve Acil Durum Yönetimi (4. Bask1). Ankara: Seçkin Yayıncılık.

Parsons, T. (1968). The Structure of Social Action - Volume I-II. New York: Free Press.

Parsons, T. (1991). The Social System (2nd Edition). New York: Routledge.

Parsons, T. (2007). An Outline of the Social System. Craig Calhoun et al. (Eds.), Classical Sociological Theory (2nd Edition) (pp. 421-440). Oxford: Wiley-Blackwell.

Phillips, B. D., Neal, D. M., \& Webb, G. R. (2012). Introduction to Emergency Management. Boca Raton: CRC Press.

Poloma, M. M. (1993). Çağdaş Sosyoloji Kuramları (çev: Hayriye Erbaş). Ankara: Gündoğan Yayınlar1.

Quarantelli, E. L. (2003). A Half Century of Social Science Disaster Research: Selected Major Findings and Their Applicability. University of Delaware Disaster Research Center, Preliminary Paper 336.

Ritzer, G. (1975). Professionalization, Bureaucratization and Rationalization: The Views of Max Weber. Social Forces, 53(4), 627-634.

Schiermer, B. (2014). Durkheim's Concept of Mechanical Solidarity-Where Did It Go? Durkheimian Studies, 20(1), 64-88.

Schwanitz, D. (1995). Systems Theory According to Niklas Luhmann: Its Environment and Conceptual Strategies. Cultural Critique, 30, 137-170.

Simonovic, S. P. (2015). Systems Approach to Management of Disasters-A Missed Opportunity?. Journal of Integrated Disaster Risk Management, 5(2), 70-83.

Stenchion, P. (1997). Development and Disaster Management. The Australian Journal of Emergency Management, 12(3), 40-44. MacMillan.

Swingewood, A. (1991). A Short History of Sociological Thought (2nd Edition). New York:

Şengün, H. (2018). Afet Yönetimin Kurumsal Yapısı ve Afet Hukuku. Hayriye Şengün, Seçil Gül Meydan Yıldız ve Binali Tercan (Ed.), Türkiye'nin Afet Yönetimi-Sosyal, Siyasal ve Yönetim Boyutlartyla içinde (ss. 133-160). Ankara: Palme Yayınevi.

Tomaszewski, B. (2020). Geographic Information Systems (GIS) for Disaster Management (2nd Edition). London: Routledge.

Turner, B. (2005). Durkheim, Emile. Kimberly Kempf-Leonard (Ed.), In: Encyclopedia of Social Measurement Vol I (A-G) (pp. 699-704). Cambridge, MA: Elsevier.

Turner, B., \& Pidgeon, N. (1997). Man-Made Disasters (2nd Edition). London: ButterworthHeinemann.

Wallace, R. A., \& Wolf, A. (2005). Comtemporary Sociological Theory: Expanding the Classical Tradition, 6th Edition. London: Pearson.

Weber, M. (1978). Economy and Society: A New Translation, edited and translated by Keith Tribe. Boston, MA: Harvard University Press.

Wortmann, S. (2007). Collective Consciousness. In George Ritzer (Ed.), The Blackwell Encyclopedia of Sociology (11th Edition) (pp. 581-583). Oxford: Blackwell Publishing.

Yıldırım, A. (2020). Örgüt Teorisinde Parsons'cu İşlevselcilik ve Gerilim Yönetimi. SDÜ Fen Edebiyat Fakültesi Sosyal Bilimler Dergisi, 51, 153-167. 


\section{EXTENDED ABSTRACT}

The history of humanity has witnessed many disasters. These catastrophic events had generally been classified into two separated areas until the 2000's: natural disasters and man-made disasters. Natural disasters are identified with the results of destructive natural events that occur spontaneously. Earthquake, tsunami, flood, and drought are the most prominent types of natural disasters. On the other hand, man-made disasters refer to the devastations in which human (mistake) plays the leading role. Nuclear explosions or nuclear wastes, water pollution, terrorist attacks, etc. are the common man-made disasters that are issued in scientific research.

After the 2000's, it has been observed that the strict distinction between natural and man-made disasters has been disappearing. The main reason behind this is the effect of human (mistake) on natural destructive events. For example, although climate change reflects the consequences of nature on the surface, the main reason for such a global natural disaster can be traced back on the over-consumption habits of people and industrial production that does not care about the "nature". On the other hand, regardless of the background/type, it is also a well-known fact that disasters strikingly and suddenly change societal life in terms of economic, cultural, organizational, and even political situation. This change lets us consider disasters as one of the sub-branches of sociology due to social impact, social consequences, and social change of society caused by any type of disaster.

The literature on the sociology of disaster has been formed by the facts mentioned above. Sociological perspectives on disasters, especially putting human (mistake) at the centre when dealing with disasters generate a new research area inside the discipline of sociology of disaster: disaster management. This area/concept mainly focuses on the struggle with the undesirable consequences of natural or man-made disasters to minimize the negative effects of disasters on society by considering the precautions and actions on pre-disaster and post-disaster phases. Integrated disaster management, which foresees more comprehensive understanding and practice regarding social effects of disasters, requires the participation of each social institution and actor in the fight against disaster. In this struggle, the professional steps, solidarity, mutuality, and favour of society are taken into consideration on the agenda. This point is actually the meeting point of integrated disaster management and classical sociology, which was developed in the late $19^{\text {th }}$ and early $20^{\text {th }}$ century. Despite contemporary sociological perspectives on integrated disaster management, initial touches of the founders of classical sociology on social life can lead us to the outputs of this concept.

In this study, the theory of social system, social structure, social function, and some of the concepts such as solidarity, division of labour, specialization, bureaucracy, and rationality, which are the classical and basic research areas of sociology, are examined in the light of their status within integrated disaster management. It is asserted that the aim of protecting social order against the negative consequences of disasters in integrated management is attributed to social system theory, which considers social processes from a functionalist insight. In relation to this, Emile Durkheim's concepts, collective consciousness and organic solidarity are highlighted by considering the scope of integrated disaster management that foresees mutual thinking and acting to protect social system against natural or man-made calamities. In addition to this, due to the complexity of official and civil actors and their relationships in the face of disasters, it is demonstrated that rationalization and bureaucracy -mainly discussed by Max Weber- in the process of disaster management are the useful starting points to understand the struggle and management before and after disasters.

These theories and concepts that are rooted in classical sociology can be observed in each phase of integrated disaster management, which are disaster moment, response, recovery, mitigation, risk reduction, prevention, preparedness. Sociological theories and concepts can be applied to each phase. For example, recovery as a post-disaster phase requires social solidarity and collective consciousness to compensate the destructive effects and consequences of any disaster. On the other hand, preparedness, which refers to pre-disaster period, would require rational estimations and specialized knowledge in order to protect people and society by taking professional precautions.

To conclude, in this "disasters age", sociology of disaster becomes a contemporary sub-discipline and integrated disaster management has been one of the most recent research areas of sociology of disaster. Their relationship has a comprehensive frame that would keep them together due to the fact and reflex of keeping society alive, compensating harms due to both natural and man-made disasters, providing people with collective consciousness by both encouraging them to respond to and being prepared for disasters. That is why, this article also asserts that classical sociology carries many tools, arguments, concepts, theories, etc. regarding contemporary disaster management processes. 